\section{Check for updates}

Cite this: RSC Adv., 2018, 8, 4680

\title{
Integrated phytoremediation focused on microbial investigation
}

\author{
T. Y. Yeh, (D) *a C. M. Kao ${ }^{\text {b }}$ and W. H. Chen ${ }^{b}$
}

Phytoremediation is an environmentally friendly green rehabilitation technology that is often incorporated with an application to improve phytohormones required for the growth of agricultural plants with the expectation to improve the effectiveness of plant rehabilitation. This study adopts phytoremediation, a green remediation technology, for the sake of restoring soil fertility and ensuring environmental sustainability, and adds ethylenediaminedisuccinic acid (EDDS) and the plant growth regulator $\left(G_{3}\right)$ to examine the overall efficiency of phytoremediation. The experiments using pots in this study finds that environmentally sustainable phytoremediation achieves the greatest efficacy regarding the remediation of soil polluted by copper, zinc and nickel. The best combination of operational factors is the addition of the EDDS and $\mathrm{GA}_{3}$. The environment where the EDDS is added shows a poorer performance in the remediation of the heavy metal lead. In addition, the PCR(Polymerase chain reaction)-DGGE analysis results of bacterial flora change show that the combination "heavy metal + EDDS $+\mathrm{GA}_{3}$ " brings about the richest bacterial flora, indicating that the addition of EDDS and $\mathrm{GA}_{3}$ can stimulate microbial growth, thereby achieving richer bacterial flora.

Received 26th May 2017

Accepted 5th July 2017

DOI: $10.1039 / \mathrm{c} 7 \mathrm{ra05895k}$

rsc.li/rsc-advances polluted soil and underground water. It is an eco-friendly green remediation technique focusing on the sustainability of environmental and ecological resources. Since plants for phytoremediation can be used to absorb and store heavy metals from the soil at polluted sites, it is also more likely to be accepted by the general public than conventional remediation. Additionally, phytoremediation is more cost-effective and suitable for complex compositions of both organic and inorganic metal pollutants in sediment or soil. Furthermore, it will not damage soil structure and texture, and people living in the remediation area will demonstrate higher acceptance toward this method. It also improves the scenery, provides more added value and function, and creates a sustainable environment. ${ }^{1}$

Consequently, sunflowers are selected for phytoremediation in this study. By integrating a plant growth hormone, $\mathrm{GA}_{3}$, as well as environmentally friendly and bio-degradable chelating agent, EDDS, this study aims to improve the effectiveness of the heavy metal contamination remediation via phytoremediation, thereby achieving environmental sustainability.

\section{Materials and method}

\subsection{Pot experiment}

The operational conditions are shown in Table 1. First, the soil from the campus of National University of Kaohsiung and nonorganic soil purchased from a gardening store are adopted in the experiment. Table 2 shows the soil parameters. Before the experiment, each pot, with the dimensions of $70 \mathrm{~cm}$ long $\times$ $30 \mathrm{~cm}$ wide, was filled with $10 \mathrm{~kg}$ soil. After filling the pots, heavy metals of $\mathrm{Cu}, \mathrm{Zn}, \mathrm{Pb}$, and $\mathrm{Ni}$ were added with 
Table 1 Operational condition of pot experiment

\begin{tabular}{ll}
\hline Parameters & Experimental condition \\
\hline Plants in pot & Sunflower $($ helianthus annuus $)$ \\
Concentration of & $\mathrm{Cu}\left(800 \mathrm{mg} \mathrm{kg}^{-1}\right), \mathrm{Zn}\left(4000 \mathrm{mg} \mathrm{k}^{-1}\right)$, \\
heavy metals & $\mathrm{Pb}\left(4000 \mathrm{mg} \mathrm{kg}^{-1}\right), \mathrm{Ni}\left(400 \mathrm{mg} \mathrm{kg}^{-1}\right)$ \\
$\mathrm{GA}_{3}$ concentration & $10^{-8} \mathrm{~mol} \mathrm{~kg}^{-1}$ \\
EDDS concentration & $500 \mu \mathrm{mol} \mathrm{kg}$ \\
Sunshine & $16 \mathrm{~h} / 8 \mathrm{~h} \mathrm{day} /$ night cycle \\
Experiment duration & 30 days \\
Pot dimension & $70 \mathrm{~cm}$ long $\times 30 \mathrm{~cm}$ wide \\
\end{tabular}

a concentration level one or two times higher than the regulatory standards announced by the Environmental Protection Administration. Concentration levels were kept low enough to prevent the sunflower from dying. The concentration levels of added heavy metals were $\mathrm{Cu}\left(800 \mathrm{mg} \mathrm{kg}^{-1}\right), \mathrm{Zn}\left(4000 \mathrm{mg} \mathrm{kg}^{-1}\right)$, $\mathrm{Pb}$ (4000 $\mathrm{mg} \mathrm{kg}^{-1}$ ), and $\mathrm{Ni}$ (4000 $\mathrm{mg} \mathrm{kg}^{-1}$ ), respectively. After the heavy metal solutions were added, we air dried the experimental soil and added $100 \mathrm{ml}$ EDDS with a concentration level of $500 \mu \mathrm{mol} \mathrm{kg}{ }^{-1}$, then had it air dry again. Afterwards, we transplanted four sunflowers to each experiment pot. The sunflowers were exposed to sunshine in a cycle of $16 \mathrm{~h} / 8 \mathrm{~h}$ (day/night). During the experiment, $50 \mathrm{ml} \mathrm{GA}_{3}$ and $500 \mathrm{ml}$ water were sprayed once every morning and evening, and the growth of the sunflowers was measured and recorded with photos every half month (15 days). The experiment lasted one month (30 days).

\subsection{Analysis of heavy metals}

Pot sunflowers were separated into roots, stems, leaves, and petals, and then baked in an oven at $104{ }^{\circ} \mathrm{C}$ for 24 hours before being cooled at room temperature. After being ground, $5.5 \mathrm{ml}$ nitric acid and $0.5 \mathrm{ml}$ hydrochloric acid respectively were added to $0.5 \mathrm{~g}$ plant parts for extraction. They were then microwavedigested using a MarsX microwave digester before being analyzed with the AA.

\subsection{Assessment of phytoextraction efficiency}

Bioconcentration factor indicates the efficiency of a plant species in accumulating a metal into its tissues from the surrounding environment. ${ }^{2}$ It is calculated as follows. ${ }^{3}$

Table 2 Background parameters of experimental soil

\begin{tabular}{lc}
\hline Soil parameters & Low organic matter soil \\
\hline $\mathrm{pH}$ & $6.73 \pm 0.16$ \\
$\begin{array}{l}\text { Organic substance (\%) } \\
\text { Background concentration of } \\
\text { heavy metal, } \mathrm{Cu}, \text { in soil }\left(\mathrm{mg} \mathrm{kg}^{-1}\right)\end{array}$ & $87.1 \pm \pm 0.27 \%$ \\
$\begin{array}{l}\text { Background concentration of } \\
\text { heavy metal, } \mathrm{Zn} \text {, in soil }\left(\mathrm{mg} \mathrm{kg}^{-1}\right)\end{array}$ & $133.5 \pm 7.3$ \\
$\begin{array}{l}\text { Background concentration of } \\
\text { heavy metal, Pb, in soil }\left(\mathrm{mg} \mathrm{kg}^{-1}\right)\end{array}$ & $0 \pm 0.01$ \\
$\begin{array}{l}\text { Background concentration of } \\
\text { heavy metal, Ni, in soil }\left(\mathrm{mg} \mathrm{kg}^{-1}\right)\end{array}$ & $9.2 \pm 1.1$
\end{tabular}

$$
\mathrm{BCF}=\frac{C_{\text {root }}}{C_{\text {soil }}}
$$

Translocation factor indicates the efficiency of the plant in translocating the accumulated metal from its roots to shoots. It is calculated as follows. ${ }^{4}$

$$
\mathrm{TF}=\frac{C_{\text {shoot }}}{C_{\text {root }}}
$$

Phytoremediation efficiency factor was calculated for pot experiment results to illustrate the phytoextraction efficiency.

$$
\mathrm{PEF}=\mathrm{BCF} \times \mathrm{TF}=\frac{C_{\text {shoot }}}{C_{\text {soil }}}
$$

In the above formula, $C_{\text {soil }}, C_{\text {root }}$ and $C_{\text {shoot }}$ represent the concentration of the soil, underground part of plants (i.e. the roots) and above parts of plants (i.e. the shoots and leaves), respectively.

\subsection{Bacterial flora analysis}

2.4.1 Denaturing gradient gel electrophoresis (DGGE). The soil sampling for the pot experiment, which contained $\mathrm{Cu}, \mathrm{Zn}$, $\mathrm{Pb}$, and $\mathrm{Ni}$ with concentration levels two times higher than the regulatory standards, was conducted by harvesting the sunflowers and collecting $100 \mathrm{~g}$ of soil respectively from each pot. After mixing soil to make it even, $100 \mathrm{~g}$ soil was collected for bacterial flora analysis. During the undertaking of the experiment, glass plates were disinfected with alcohol, and placed on the holders of the gel caster covered with sponge before being stabilized with clamps. Afterward, the bottom gel was produced. First, we prepared $0.1 \mathrm{~g} 10 \%$ APS (ammonium persulfate) with $1 \mathrm{ml}$ of deionized water, and added reagents to a centrifuge tube in the following order: $1.68 \mathrm{~g}$ Urea, $1.6 \mathrm{ml}$ foramide, $1.2 \mathrm{ml}$ acrylamide/bis, and $0.1 \mathrm{ml} 50 \times$ TAE buffer; we then added $\mathrm{ddH}_{2} \mathrm{O}$ to a total volume of $16 \mathrm{ml}$, and finally added $5.3 \mu \mathrm{l}$ TEMED and $53 \mu \mathrm{l}$ of $10 \%$ APS. After mixing well, we poured $1,600 \mu \mathrm{l}$ of the solution onto the gel caster and further pressed $1,600 \mu \mathrm{l}$ of isopropanol onto the top of the gel. We then waited about 30 minutes. After the bottom gel was desiccated, we decanted the isopropanol. Then the two types of top gel with different concentration levels were produced respectively in the following steps. First of all, for the top gel with a $35 \%$ concentration, we added $2.25 \mathrm{~g}$ urea, $2.40 \mathrm{ml}$ foramide, $2.4 \mathrm{ml}$ acrylamide/bis, and $0.32 \mathrm{ml} 50 \times$ TAE buffer. Then, we added $\mathrm{ddH}_{2} \mathrm{O}$ to a total volume of $16 \mathrm{ml}$, followed by the addition of $6.4 \mu \mathrm{l}$ TEMED and $64 \mu \mathrm{l} 10 \%$ APS. For the top gel with a $57.5 \%$ concentration, we added $3.86 \mathrm{~g}$ urea, $3.68 \mathrm{ml}$ foramide, $2.4 \mathrm{ml}$ acrylamide/bis, and a $0.32 \mathrm{ml} 50 \times$ TAE buffer. Then, $\mathrm{ddH}_{2} \mathrm{O}$ was added to a total volume of $16 \mathrm{ml}$, with $6.4 \mu \mathrm{l}$ TEMED and $64 \mu \mathrm{l}$ $10 \%$ APS added finally. After preparation, the solutions were properly mixed and kept in ice at a low temperature. Gels with two different concentration levels were prepared and put into syringes, which were then placed on the platform for gradient formation. After setting them aside for about 15 minutes, we inserted combs and added a small amount of APS to each well to 
facilitate polymerization. After about two hours, when the gel had polymerized, we pulled out and cleaned the combs with $\mathrm{ddH}_{2} \mathrm{O}$, and used syringes to draw out the liquid inside the wells. Then, we placed the gel onto the platform before adding PCR products to the wells. Polymerase chain reaction (PCR) is a technique used in molecular biology to amplify a single copy or a few copies of a piece of DNA across several orders of magnitude, generating thousands to millions of copies of a particular DNA sequence.

Purified PCR products were quantified and sized. After that, they were added to the denaturing gradient gel for DGGE preparation. First, we turned on the heating system of the electrophoresis tank to preheat the running buffer $(1 \times$ TAE buffer) to $60{ }^{\circ} \mathrm{C}$ so that the DNA could undergo the denaturing gradient effect at a stable temperature during the process. Then Perist, a liquid cycling system, was turned on and the denaturing gradient gels were put into the electrophoresis tank. Afterwards, the PCR products mixed with loading dye were put in the groove above the denaturing gradient gel. Finally, electrophoresis was conducted with a lower voltage of 65 volts at a temperature of $60{ }^{\circ} \mathrm{C}$ for 14.5 hours.

2.4.2 SYBR green I for DNA staining. In order to have the most complete examination on the bacterial flora of microorganism in soil, we increased not only the DNA contents but also chose a DNA staining dye with higher sensitivity. Normally, DNA staining dyes, in the order of sensitivity, are SYBR green I > silver staining $>$ ethidium bromide. Thus, this experiment adopted SYBR green I for DNA staining. ${ }^{5}$ The denaturing gradient gels were carefully extracted from the electrophoresis system and placed on trays. They were then cleaned with deionized water more than three times. Afterward, SYBR green I staining was conducted; we put the denaturing gradient gels in the $200 \mathrm{ml} 1 \times$ TAE buffer solution with $20 \mu \mathrm{l} \mathrm{SYBR}$ green I (amresco), and shook the solution at the speed of $150 \mathrm{rpm}$ for 1 hour. When SYBR green I staining is being conducted, treatment should occur away from light. After staining, the LAS-3000 Luminescent image analyzer (FUJIFILM) was used for fluorescence excitation and image capture.

\section{Result and discussion}

\subsection{Correlation analysis of plant growth differences and concentration levels of heavy metals in soil}

As shown in the comparison of each group's overall growth in height (Fig. 1), the group with $\mathrm{GA}_{3}$ added showed greater height and weight growth in comparison to the group with only $\mathrm{Cu}$ added, which proved the effectiveness of adding $\mathrm{GA}_{3}$ to promote plant growth; meanwhile, the group with EDDS added showed less growth in height and weight in comparison to the others. Previous research indicated that a chelating agent can assist in increasing the absorption of heavy metals in plants. However, it can also increase toxicity in plants. ${ }^{6}$ Thus, the group with EDDS added showed less growth in height and weight in comparison to the others. However, the group with EDDS $+\mathrm{GA}_{3}$ added grew taller and heavier than the group with EDDS added, which indicated that the addition of $\mathrm{GA}_{3}$ can effectively protect sunflowers from the impact of adding EDDS.

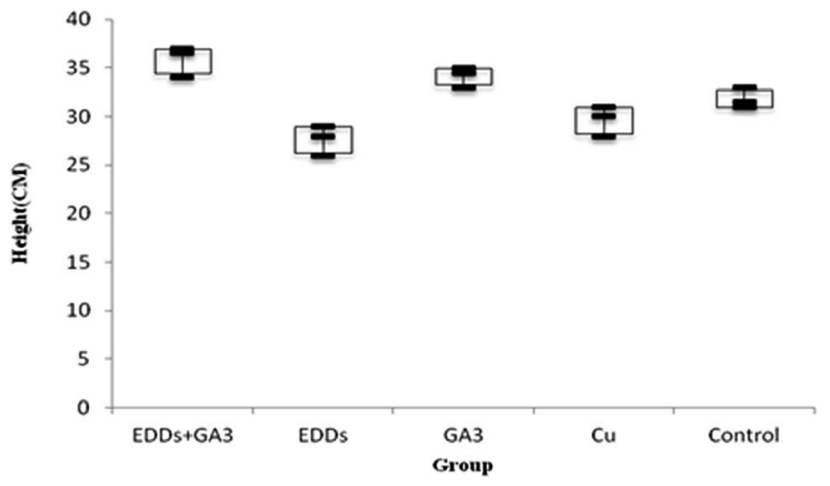

Fig. 1 Comparison of total plant growth in height among the groups with $\mathrm{Cu}$ added.

Hence, according to the comparison of total growth in height among the groups with $\mathrm{Cu}$ added (Fig. 1), the group with EDDS $+\mathrm{GA}_{3}$ is more suitable for application to the phytoremediation of soil at a concentration level of $\mathrm{Cu}$.

As shown in total growth of height comparisons for each group (Fig. 2), the group with EDDS added showed inhibited plant growth in the soil with a concentration level of $\mathrm{Zn}$. Among the groups in the experiment, the group with EDDS $+\mathrm{GA}_{3}$ added showed greater growth in weight and height than that of the other groups. EDDS in the soil with $\mathrm{Zn}$ added at a concentration still promotes the growth of plant to a certain level, which indicates that $\mathrm{Zn}$ is not so toxic to sunflowers, and that the addition of $\mathrm{GA}_{3}$ to the soil added with $\mathrm{Zn}$ at a concentration can effectively inhibit the disadvantage of a chelating agent to plant growth.

Hence, after comparing height and weight for plant growth, the group with EDDS $+\mathrm{GA}_{3}$ added is more suitable for application to the phytoremediation of soil at a concentration level of $\mathrm{Zn}$.

As shown in the comparison of total growth in height among each group (Fig. 3), the group with EDDS showed significantly lower growth in plant height in the soil with concentration level of $\mathrm{Pb}$ than the group with $\mathrm{GA}_{3}$ and the group with EDDS $+\mathrm{GA}_{3}$. The result indicates that $\mathrm{GA}_{3}$ can still effectively inhibit the disadvantage of a chelating agent for plants grown in the soil with $\mathrm{Pb}$ at a concentration. Besides, the group with EEDS

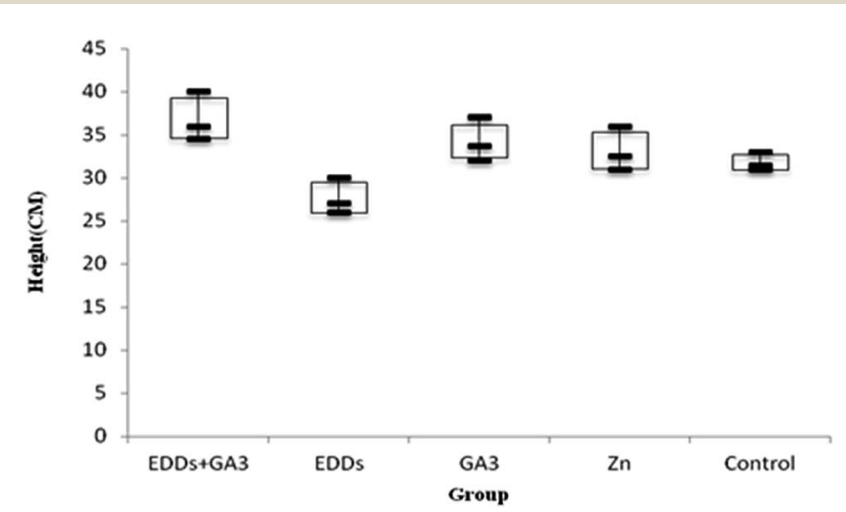

Fig. 2 Comparison of total plant growth in height among the groups with $\mathrm{Zn}$ added. 


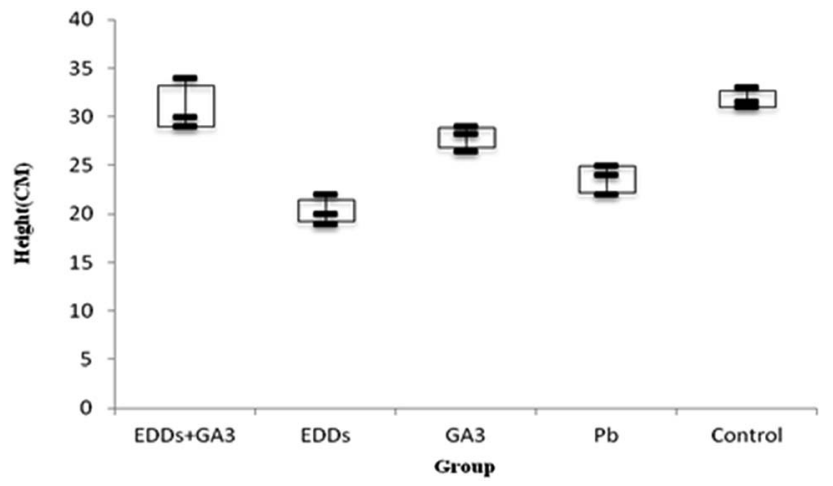

Fig. 3 Comparison of total plant growth in height among the groups with $\mathrm{Pb}$ added.

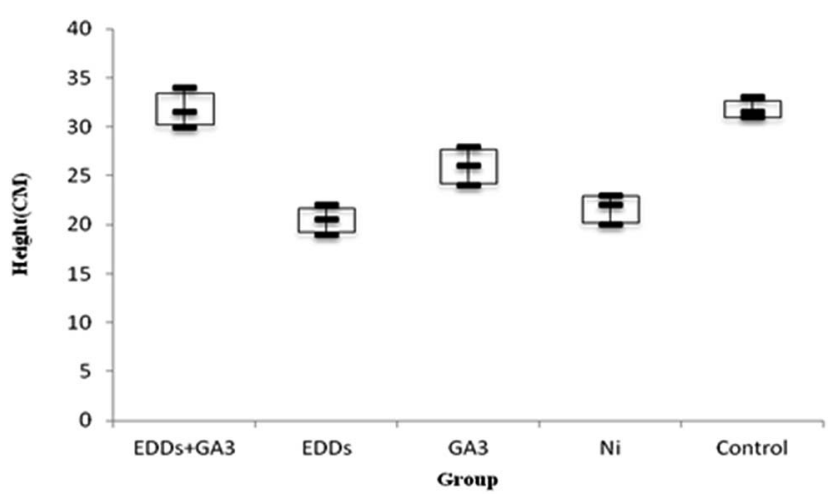

Fig. 4 Comparison of total plant growth in height among the groups with $\mathrm{Ni}$ added.

showed lower growth in plant height than the group with only $\mathrm{Pb}$, which explains why the addition of a chelating agent can increase the effectiveness of sunflowers in absorbing heavy metals, but also increase the toxicity to sunflowers.

Hence, after comparing plant height and weight growth, the group with EDDS $+\mathrm{GA}_{3}$ is more suitable for application to the phytoremediation of soil at a concentration level of $\mathrm{Pb}$.

As shown in totals for comparisons of how much each group grew (Fig. 4), the group with EDDS inhibits plant height growth in the soil with a concentration level of $\mathrm{Ni}$. Among the groups in the experiment, the group with $\mathrm{GA}_{3}$ and the group with EDDS $+\mathrm{GA}_{3}$ grew significantly higher than the group with EDDS and the group only with $\mathrm{Ni}$.

Hence, according to the comparison of total height among the groups with $\mathrm{Ni}$ added (Fig. 4), the group with EDDS $+\mathrm{GA}_{3}$ is more suitable for application to the phytoremediation of soil at
Table 4 Pot experiment: BCF value comparison at a concentration

\begin{tabular}{lllll}
\hline & $\begin{array}{l}\text { EDDS }+ \\
\text { Group }\end{array}$ & EDDS & $\mathrm{GA}_{3}$ & $\begin{array}{l}\text { Heavy metal } \\
\text { only }\end{array}$ \\
\hline $\mathrm{Cu}$ & 0.26 & 0.20 & 0.11 & 0.12 \\
$\mathrm{Zn}$ & 0.29 & 0.16 & 0.10 & 0.11 \\
$\mathrm{~Pb}$ & 0.05 & 0.03 & 0.01 & 0.02 \\
$\mathrm{Ni}$ & 0.37 & 0.52 & 0.36 & 0.26
\end{tabular}

a concentration level of $\mathrm{Ni}$ one time higher than regulatory standards.

\subsection{Discussion on the concentration of soil and the absorbed heavy mental of sunflowers}

We examined the total heavy metal contents of sunflower plants. From the comparison of total heavy metals absorbed by plants in each group (Table 3), we were able to determine total heavy metals absorbed by sunflowers planted in soil containing $\mathrm{Cu}, \mathrm{Zn}, \mathrm{Pb}$, and $\mathrm{Ni}$ at a concentration level two times higher than regulatory standards during the phytoremediation in this experiment. First, we compared the groups using $\mathrm{EDDS}+\mathrm{GA}_{3}$ to the groups with only heavy metals, and we found that, in the soil containing $\mathrm{Cu}, \mathrm{Zn}, \mathrm{Pb}$, and $\mathrm{Ni}$ at the concentration level two times higher than regulatory standards, the former indeed saw an increase in overall heavy metal accumulation in the sunflower, especially for the soil containing $\mathrm{Cu}, \mathrm{Zn}$, and $\mathrm{Ni}$. However, there was no significant difference for the soil containing $\mathrm{Pb}$.

Next is the comparison between the use of EDDS $+\mathrm{GA}_{3}$ and the addition of $\mathrm{GA}_{3}$ only. The comparison of heavy metal absorption in each group of sunflowers (Table 3) indicates the group with $\mathrm{GA}_{3}$ absorbs lower total volumes of heavy metals than the groups with EDDS $+\mathrm{GA}_{3}$ and with EDDS only. Since EDDS can improve the mobility of heavy metals in soil and the heavy metal absorption of roots, the total volume of heavy metal absorption for the group with $\mathrm{GA}_{3}$ is lower than those with EDDS $+\mathrm{GA}_{3}$ and with EDDS. The difference is especially evident in the soil containing $\mathrm{Cu}, \mathrm{Zn}$, and $\mathrm{Ni}$, but the difference in the soil containing $\mathrm{Pb}$ is not obvious.

\subsection{Discussion on phytoremediation efficacy in soil at a concentration}

First, the BCF values shown in Table 4 mainly present the comparison of heavy metal accumulations in roots, as well as the heavy metal content in soil. Higher BCF values indicates better heavy metal absorption. We compared the BCF values of

Table 3 Pot experiment: total heavy metal contents absorbed by sunflowers in each group

\begin{tabular}{lccrl}
\hline Group & EDDS $+\mathrm{GA}_{3}$ & EDDS & \multicolumn{1}{c}{$\mathrm{GA}_{3}$} & Heavy metal only \\
\hline $\mathrm{Cu}$ & $172.4 \pm 3.9 \mathrm{mg} \mathrm{kg}^{-1}$ & $121.9 \pm 4.7 \mathrm{mg} \mathrm{kg}^{-1}$ & $90.2 \pm 5.6 \mathrm{mg} \mathrm{kg}^{-1}$ & $80.9 \pm 4.0 \mathrm{mg} \mathrm{kg}^{-1}$ \\
$\mathrm{Zn}$ & $1005.6 \pm 21.3 \mathrm{mg} \mathrm{kg}^{-1}$ & $547.4 \pm 13.2 \mathrm{mg} \mathrm{kg}^{-1}$ & $411.2 \pm 11.2 \mathrm{mg} \mathrm{kg}^{-1}$ & $325.9 \pm 7.2 \mathrm{mg} \mathrm{kg}^{-1}$ \\
$\mathrm{~Pb}$ & $88.6 \pm 5.4 \mathrm{mg} \mathrm{kg}^{-1}$ & $63.3 \pm 3.1 \mathrm{mg} \mathrm{kg}^{-1}$ & $49.1 \pm 4.7 \mathrm{mg} \mathrm{kg}^{-1}$ & $46.2 \pm 2.3 \mathrm{mg} \mathrm{kg}^{-1}$ \\
$\mathrm{Ni}$ & $161.2 \pm 5.9 \mathrm{mg} \mathrm{kg}^{-1}$ & $137.0 \pm 3.6 \mathrm{mg} \mathrm{kg}^{-1}$ & $143.2 \pm 4.1 \mathrm{mg} \mathrm{kg}^{-1}$ & $71.4 \pm 3.5 \mathrm{mg} \mathrm{kg}^{-1}$
\end{tabular}


Table 5 Pot experiment: TF value comparison at a concentration

\begin{tabular}{lllll}
\hline Group & $\begin{array}{l}\text { EDDS }+ \\
\mathrm{GA}_{3}\end{array}$ & EDDS & $\mathrm{GA}_{3}$ & $\begin{array}{l}\text { Heavy metal } \\
\text { only }\end{array}$ \\
\hline $\mathrm{Cu}$ & 2.30 & 2.09 & 3.23 & 2.26 \\
$\mathrm{Zn}$ & 2.39 & 2.44 & 3.25 & 2.03 \\
$\mathrm{~Pb}$ & 0.82 & 0.96 & 1.51 & 1.16 \\
$\mathrm{Ni}$ & 3.32 & 1.63 & 2.98 & 1.78
\end{tabular}

groups with only heavy metals to those with EDDS, with $\mathrm{GA}_{3}$ and with EDDS $+\mathrm{GA}_{3}$. Table 4 present the comparison of the soil for concentration levels of $\mathrm{Cu}, \mathrm{Zn}$, and $\mathrm{Pb}$. The result shows that the $\mathrm{BCF}$ value of the EDDS $+\mathrm{GA}_{3}$ group is the highest, and there is no significant difference for the groups with $\mathrm{EDDS}+\mathrm{GA}_{3}$ at concentration levels of $\mathrm{Cu}, \mathrm{Zn}$, and $\mathrm{Pb}$. Such results indicate the addition of EDDS and $\mathrm{GA}_{3}$ together can effectively improve the heavy metal absorption of sunflower roots, and the efficacy of the roots' absorption remains unchanged as the concentration of heavy metals increases. After comparing Table 4, we found that the group with EDDS show optimal performance, followed by those with EDDS $+\mathrm{GA}_{3}$ in the soil at a concentration level of $\mathrm{Ni}$. The results show the addition of EDDS in the soil containing $\mathrm{Ni}$ actually improves sunflower root absorption.

$\mathrm{TF}$ value refers to the comparison of heavy metal contents of parts above the ground (stem, leave, and petal) with those of roots in order to examine the mobility of heavy metals from roots to parts above the ground. Higher TF value indicates better mobility from roots to parts above the ground. Since $\mathrm{GA}_{3}$ promotes the growth of plant parts above the ground by bringing more nutrition from roots, xylem, to the parts above the ground, we examine its efficacy to see if it brings nutrition and heavy metals together to parts above the ground. According to Table 5 , the group with $\mathrm{GA}_{3}$ has the highest TF value in soil at the concentration level of $\mathrm{Cu}$, indicating the adding $\mathrm{GA}_{3}$ effectively promotes the mobility of $\mathrm{Cu}$ to sunflower parts on the ground. However, when comparing Table 5, we found there is no significant difference among the group with $\mathrm{EDDS}+\mathrm{GA}_{3}$, the group with $\mathrm{GA}_{3}$, and the group with heavy metals only. This also proves the absorption efficacy of sunflower parts is not reduced in the soil containing heavy metals. Furthermore, when comparing Table 5 to examine the absorption efficacy of $\mathrm{Zn}$ in soil at a concentration, we found the value of $\mathrm{GA}_{3}$ group increases greatly as the concentration level of $\mathrm{Zn}$ increases in the soil, indicating the addition of $\mathrm{GA}_{3}$ can effectively increase $\mathrm{Zn}$ mobility of the sunflower and the absorption of sunflower parts above the ground. Table 5 also show, in comparing the data of concentration levels of $\mathrm{Pb}$, there are no significant

Table 6 Pot experiment: PEF value comparison at a concentration

\begin{tabular}{lllll}
\hline & $\begin{array}{l}\text { EDDS }+ \\
\text { Group }\end{array}$ & EDDS & $\mathrm{GA}_{3}$ & $\begin{array}{l}\text { Heavy metal } \\
\text { only }\end{array}$ \\
\hline $\mathrm{Cu}$ & 0.60 & 0.41 & 0.35 & 0.28 \\
$\mathrm{Zn}$ & 0.71 & 0.39 & 0.31 & 0.22 \\
$\mathrm{~Pb}$ & 0.04 & 0.03 & 0.03 & 0.02 \\
$\mathrm{Ni}$ & 1.24 & 0.85 & 1.07 & 0.46
\end{tabular}

differences for values among most of the groups, except the group with $\mathrm{GA}_{3}$. Finally, comparing the soil at the concentration level of $\mathrm{Ni}$, the data shown in Table 6 indicates that the TF values of the most of the groups reduce when the concentration

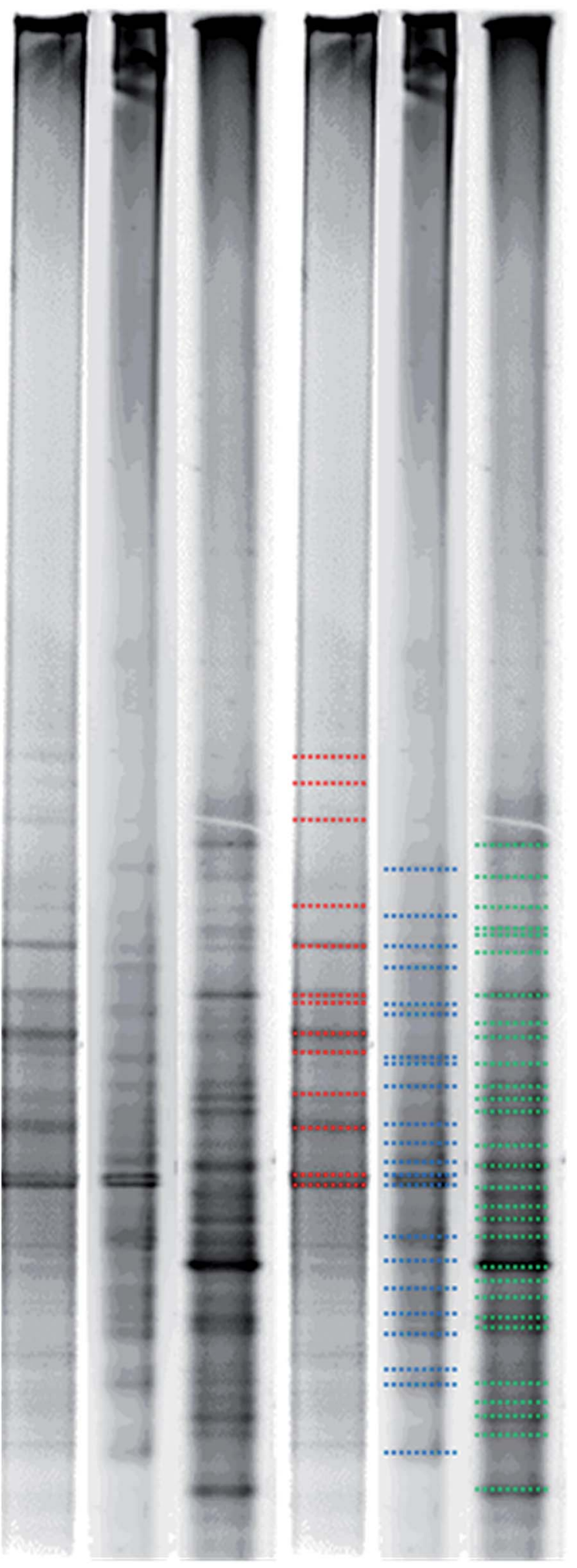

Fig. 5 DGGE bacterial flora analysis of test groups. 
of $\mathrm{Ni}$ in the soil increases, but the group with EDDS rises when the concentration increases. This indicates the addition of EDDS can effectively assist sunflowers in transmitting Ni from roots to parts above the ground.

The last item we would like to examine is PEF value, the comparison of overall phytoremediation. The data shown in Table 6 present the comparison of the overall efficacy of the phytoremediation at the concentration levels of $\mathrm{Cu}, \mathrm{Zn}, \mathrm{Pb}$ and $\mathrm{Ni}$, and the result shows adding EDDS and $\mathrm{GA}_{3}$ together is optimal for phytoremediation. In addition, the data shown in Table 6 present that there was no significant difference for PEF values between the soil at the concentration level of $\mathrm{Cu}, \mathrm{Zn}$, and $\mathrm{Pb}$. The result indicates that even if the concentration level of $\mathrm{Cu}, \mathrm{Zn}$, and $\mathrm{Pb}$ in the soil increases by two times, there are no significantly increasing or reducing efficacy for overall phytoremediation; however, when the concentration level of $\mathrm{Ni}$ is increased by two times, the efficacy is greatly reduced relatively. This indicates that the efficacy of the phytoremediation will decrease when the concentration of Ni increases.

From the above results we can draw conclusions concerning the optimal operating parameters for sustainable phytoremediation. In the soil containing $\mathrm{Cu}, \mathrm{Zn}$, and $\mathrm{Ni}$, the addition of EDDS and $\mathrm{GA}_{3}$ together shows much higher PEF values than that of any of other groups. Thus, adding EDDS and $\mathrm{GA}_{3}$ together is a suitable option for the phytoremediation of $\mathrm{Cu}, \mathrm{Zn}$, and $\mathrm{Ni}$. As to the soil containing $\mathrm{Pb}$, we need to look for another means of remediation which has more efficiency.

In conclusion, the above results prove the addition of EDDS and $\mathrm{GA}_{3}$ for phytoremediation can be more helpful to the heavy metal absorption and accumulation of plants in comparison to conventional phytoremediation. It can also improve the efficiency of remediation, and shorten the required time for the whole procedure.

\subsection{Discussion on impact of phytoremediation on heavy metal-polluted soil and bacterial flora}

Fig. 5 shows bacterial flora change in three test groups after the PCR and DGGE analysis. According to Fig. 5, there are 13 bands of the heavy metal $+\mathrm{H}_{2} \mathrm{O}$ (marked with red color); there are 22 bands of heavy metals $+\mathrm{GA}_{3}$ (marked with blue color); and there are 29 bands of heavy metals + EDDS + DGA $_{3}$ (marked with green color). DGGE analysis is conducted by using gradient screening after enlarging and purifying DNA sections. When a band appears, it indicates the dominant bacteria group. As a result, the more bands in a sample, the richer bacterial flora in the sample, and the higher possibility of diverse microorganisms.

\section{Conclusion and suggestion}

\subsection{Conclusion of pot experiment}

The pot experiment in this study examines and determines the optimal operational group. The researchers planted sunflowers in the soil containing $\mathrm{Cu}, \mathrm{Zn}, \mathrm{Pb}$, and $\mathrm{Ni}$, and compared their growth status, total contents of heavy metals in their roots, as well as parts above the ground (stem, leave, and petal), then examined the effective coefficient of phytoremediation. The results show the addition of EDDS can effectively promote the heavy metal mobility, and increase the heavy metal absorption of plants; while the addition with $\mathrm{GA}_{3}$ can increase the biomass of plants and improve upward mobility of plants. Finally, the pot experiment indicates that adding EDDS and $\mathrm{GA}_{3}$ together can generate the best absorption efficacy in the soil containing $\mathrm{Cu}, \mathrm{Zn}$, and $\mathrm{Ni}$.

As to the selection of a chelating agent, the use of EDDS has the best effect on remediation for the soil containing $\mathrm{Cu}, \mathrm{Zn}$, and Ni. Moreover, EDDS can be decomposed by microorganisms in the soil. Thus, it will not result in acid soil or secondary pollution like a chemical chelating agent. However, EDDS has less efficacy for soil polluted by $\mathrm{Pb}$. As a result, we suggest looking for other biodegradable chelating agents to remedy $\mathrm{Pb}$ polluted soil more effectively.

Consequently, the pot experiment demonstrates the environmentally sustainable phytoremediation possesses optimal efficacy in remedying soil polluted by $\mathrm{Cu}, \mathrm{Zn}$, and $\mathrm{Ni}$, and the optimal method is adding EDDS and $\mathrm{GA}_{3}$ together. However, EDDS is not suitable for the remediation of $\mathrm{Pb}$ polluted environments.

\subsection{Conclusion of the impact of phytoremediation on bacterial flora in soil}

According to bacterial flora change result acquired from PCR and DGGE analysis, among the three groups, heavy metal + $\mathrm{H}_{2} \mathrm{O}$, heavy metal $+\mathrm{GA}_{3}$, and heavy metal + EDDS $+\mathrm{GA}_{3}$, the last group has the richest bacterial flora. This demonstrates that when EDDS and $\mathrm{GA}_{3}$ are added together, the growth of microorganisms will be stimulated to create the richer development of bacterial flora.

\section{Conflicts of interest}

There are no conflicts to declare.

\section{References}

1 H. Ali, E. Khan and M. A. Sajad, Chemosphere, 2013, 91, 869881.

2 S. Ladislas, A. EI-Mufleh, C. Gerente, F. Chazarenc, Y. Andres and B. Bechet, Water, Air, Soil Pollut., 2012, 223, 877-888.

3 P. Zhuang, Q. Yang, H. Wang and W. Shu, Water, Air, Soil Pollut., 2007, 184, 235-242.

4 P. K. Padmavathiamma and L. Y. Li, Water, Air, Soil Pollut., 2007, 184, 105-126.

5 N. Bano and J. T. Hollibaugh, Appl. Environ. Microbiol., 2002, 68, 505-518.

6 M. W. H. Evangelou, M. Ebel and A. Schaeffer, Chemosphere, 2007, 68, 989-1003. 